\title{
Benchmarking Mexico \& Brazil Open Government Websites: Model and Metrics
}

\author{
Rodrigo Sandoval-Almazan ${ }^{1}$, Fabro Steibel ${ }^{2}$ \\ ${ }^{1}$ Facultad de Contaduría y Administración, Universidad Autonoma del Estado de México, Toluca, México; ${ }^{2}$ Programa de Pós- \\ Graduação em Comunicação, Universidade Federal Fluminense, Rio de Janeiro, Brazil. \\ Email: rsandovala@uaemex.mx
}

Received August $28^{\text {th }}, 2013$; revised September $27^{\text {th }}, 2013$; accepted October $3^{\text {rd }}, 2013$

Copyright (C) 2013 Rodrigo Sandoval-Almazan, Fabro Steibel. This is an open access article distributed under the Creative Commons Attribution License, which permits unrestricted use, distribution, and reproduction in any medium, provided the original work is properly cited.

\begin{abstract}
Latin American open government websites have not been compared or benchmarked. However, this is a key to assess and understand the open government impact on Latin American countries. The purpose of this paper is to introduce a model to assess open government websites and to compare Mexican and Brazilian portals related on open government and transparency practices. The result shows different levels of innovations and similarities on the interpretation of open government budget portals. Our paper will be divided into five sections. The first section will be an introduction where we address our research question and summarize the Mexican and Brazilian context; the second section is a literature review about open government; the third section is a methodology section which proposes the research model and research design; the fourth section discusses the main findings and the last section presents some conclusions and future research.
\end{abstract}

Keywords: Open Government; e-Government; Benchmarking

\section{Introduction}

Open government's trend of public administration has arrived to Latin American countries. However, very few researches have been done to understand the impact of open government and the implementation advances across in the region. Some previous research has focused on the conceptual area [1] while others have focused on the implementation of web 2.0 technologies [2-4], metrics [5] or describing experiences of open government in different countries [6-8].

The purpose of this paper is to present a combined effort to compare Mexico with Brazil initiatives of open government websites. There are very few initiatives to compare and benchmark implementations efforts on this field, which points to a difficulty to address recommendations or best practices that can be implemented by governments and policy makers in the region. We argue, as others have done, that evaluation model and the comparison between websites are the first steps to understand this new field of open government [9].

For such purpose five sections of the paper are divided as the follow: this introduction will present the context of the two countries-Mexico and Brazil—and compare the background of the two case studies' open government contexts. The second section of the paper will provide a theoretical framework of this field, followed by a third section that presents the model of analysis and the methodological considerations for this research. Fourth section discusses main findings and comparison of the two countries, and finally the last section will present some conclusions and future research lines.

\subsection{Mexico's Open Government Context}

Open government in Mexico has been a parallel effort along with democratic trends. When president Vicente Fox (right wing PAN) took power on 2000 after 70 years of dominant ruling party PRI, changes to release information and open government started on 2001 when Mexican government promoted the first law of Accountability and Open Government act; this law mandates all levels of government to diffuse several aspects of the government task using electronic means [10].

There are previous backgrounds of a transparency or freedom of information law that achieves such purposes. This law promotes the use of websites along federal, local and municipal governments, which mostly present the 
requirements of the law such as: address book of public servants, wages, data from the government offices, government expenses and law archives among others.

This is partially accomplished because main governmental officials provide the information on large PDF files or lists with different numbers or codes to identity the rank but very few of them make public the real wages, ranks with names and address of the public servants.

The Open Government act also creates the Federal Institute for Information Access (IFAI) who is responsible to promote, organize, force and penalize all government agencies to open government data in all levels [11].

Also through the IFAI they support the Open Government Partnership initiative held since September 2011, and committed to achieve ten goals of open government characteristics of the impact of the open government act into the 32 local governments, was perform by the Center of Research and Economic Teaching (CIDE), which is a non-centralized public research center that promotes the first comparative study to accomplish law requirements on 2005 [12].

The next step was developed on 2007 to measure open government portals accomplish of the law but also the usability and design of the websites. The first measure was developed by using an instrument that was applied online, the main outcome was that from 32 states, only 27 states have open government portals with reduced openness among their characteristics [13].

After this comparative study followed another ranking studies during 2009, 2010 and lastly the 2011 and 2012 measurements, some changes have been made to the instruments in order to measure more accurately several aspects such as accountability and information flow or access from the 2009 and 2010 studies [14]. On the other side, the CIDE along the Council of Mexican Open Access websites (COMAIP) produces another in-depth study on (2011) that includes interviews to most of the open government websites and requirements to measure the speed and quality of response [15].

The main findings of both studies reflect a maturity and increase of the openness among local government portals in Mexico, however most of them have different levels of achievements [16]. So far there are not researches over the federal government websites neither other government levels such as municipalities nor legislative and judiciary levels that are required to have an open government portal by law.

\subsection{Brazils' Open Government Context}

The Freedom of Access Law in Brazil (12.527/11) was approved in November 2011, and further regulated in May 2012 (7.724/12). The Bill outlines a right to information, sustaining that all information is public unless explicit reason for secrecy is given. In a comparative perspective, by the end of 2008 ten countries in Latin America had enacted freedom of information laws, already late when compared to most templates of freedom of information laws that emerged during from the 1960s to the 1980s. The first open government initiatives dated from the mid 2000s [17-19] including the event in 2004 when the first federal government transparency portal was launched [20,21]. The 2011 Bill in Brazil nonetheless brought some elements of innovation, by simultaneously regulating rights of information and specific open-data provisions to implement such rights.

The Freedom of Access Law sets some minimum criteria to disclosure of information and minimum standards that government websites must provide. The open government initiative is supported by a group of institutions from all branches of government, leaded by one Executive Branch agency: the Office of the Comptroller General (in Portuguese, the Controladoria Geral da União, CGU). In regards of budget transparency matters, the federal government creates a national website that presents information from all levels of government. State level websites (and eventually, municipal level websites, or websites from other branches of government), generally diverge in terms of design, open data tools, and level of detail provided. It is known however from previous analysis that most of Brazilian portals focus on preliminary aspects of open government, such as providing information, rather than providing tools for collaborative policy making or civil society engagement $[22,23]$.

\section{Literature Review}

When Parks [24] wrote, in the 50s, "The Open Government principle: applying the right to know under the constitution" article, a new field of research becomes the open government trend. Addressing the importance of information rights and the freedom of information for the US Government, the article discusses how war secrets are related to open government principles. The Cold war created another informational barrier to open government information; Beer research on Japan leads to another stream of knowledge about open government and freedom information [25], what lead to a debate on arguments and theoretical frameworks to understand the uses and limits of government records and informational management [26-28].

In the following years similar efforts to push freedom of information and guarantee this idea as a main right were developed. Bertil [29] research in four Nordic countries states found procedures to provide access to official records; Okudaira [30] analyzes the differences in freedom of information and the way that discretionary secrecy in the UK and the obstacles of the government to release information [31]. Hubbertz [32,33] research on the Crown corporation in Canada revels some troubles of 
making public information as an openness condition; and others have focused on freedom of information acts and the electronic dissemination of practices within Federal agencies [34] or transnational governmental organizations, such as the EU [35].

In the last decade several scholars have been promoting the concept of open government, openness and freedom of information [1,36-40]. However the Barack Obama's administration launched the open government initiative in the early days of his presidency [41] has been push the debate over the Open government worldwide, and take new steps toward a more concrete tasks to introduce accountability, freedom of information, open data and disclosure of classified information and the use of web 2.0 technologies to promote it [42-44].

Following this idea, a different stream of research is the proposal of $[31,32,34-38,40]$ who combined a perspective between FOI and open government as a tool is the idea of stewardship that states on one side the regulatory purpose of the government as a gatekeeper, on the other side promotes the idea of citizens' obligation and share responsibility of the data along with the government. Even this continue debate about open government and transparency, we define open government as an institutional and technological platform that turns the governmental data into opened data to allow its use, protection and collaboration on the part of the citizens.

According to this concept we believe that open government conceptual evolution from 1950s to date has been adapted to a new technological environment, in which technologies has take part as an important role for promoting, organize and publish government data and process. Most recent research is a proof of this link among internet technology and open government efforts [45-47].

\section{Open Government Model for Assessing Websites}

Our research model for assessing open government online is a consequence of this technological and economical environment [48], but also to the new trends of globalization and technology that invaded the world in recent years [49]. The components of the model come from four different theoretical frameworks that complement each other: 1) The new economy; 2) The open data; 3) The Networked state and 4) The New Institutionalism and the sociotechnical framework.

The information and technology communication changes have transformed the way people interact with business and government. Tapscott \& Williams [50] develop a framework to explain such changes using the idea of wikinomics, in which principles are the collaboration, co-production, outsourcing, prosumers and the internet as a platform to organize production and generates value, this concept integrates the idea of openness and transparency. Further research has been place this idea as a central category to explain the use of web 2.0 features and changes on e-government [46,51].

The second framework comes directly from the relationship between new technologies and information systems named as open data. Geiger \& and vol Lucke concept of open data refers to "storage data on the public sector that can be accessible and part of the public interest without restrictions of use and distribution" [52]. The idea is brought forward by Tim O'Reilly initiative to create a framework for open data based on eight principles, what we adopted with some modification in our benchmark model [53].

Our third concept is the Networked state, conceived from the idea that open government has a common background with the new changes and transformations of the state due the technological emergence. [54] ideas that internet changes trust, privacy and confidence on the state places a different direction of a new kind of state, named the fifth state [55]. Castells [56] agrees with Dutton and defines this new kind of state "the new state network is characterized to share the sovereignty and the responsibility between different states and levels from government; the flexibility in the procedures of government and a greater diversity of times and spaces in relationship among citizens and government..." [56].

The last framework are two interrelated concepts: the new institutionalism $[57,58]$ and the sociotechnical theory [59] in which we intent to interpret how public officials and citizens interact in the government organization. The four frameworks interact each other to develop components of the assessment model explained in the next section.

\section{Methodology}

This section is divided in two subsections: the proposal of the research model to assess open government portals and the description of the sample and the instrument linked to the model.

\subsection{Research Model}

The research model is based on the experience of five years research assessing open government websites [14] and also support on the previous literature research. The model is based on five main components: legal obligations, open data, collaboration, co-production and institutional arrangements (See Figure 1).

The legal obligations refers to the official requirements of each government-municipal, local or federal governments, this component comes from the normative idea of Institutionalism Dimaggio [57] and the Orlikowsky [59] theoretical framework.

The open data component's main idea is to make the 


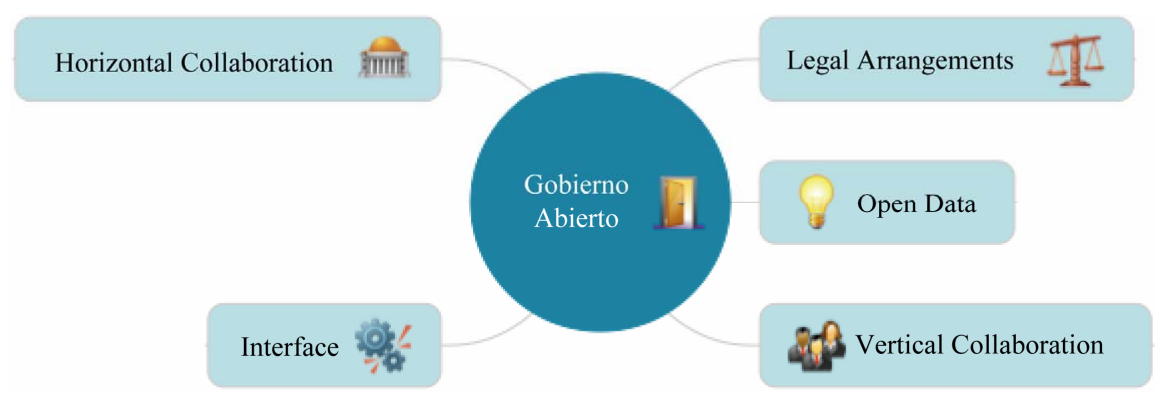

Figure 1. Open government assessment model.

government data public in two ways: 1) generating trust in the government, and 2) using information technologies such as information systems, to make this open data of easy access, friendly interfaces and with usability standards. We consider the O'Reilly Open Government Working Group (2007) to analyze this component.

The leading idea of collaboration is to produce improvements in the open government portals. The previous component focused on measuring tools or sections on the website, directly related to improving the open government portals; linking different collaborations in order to strengthen the idea of promoting citizens participation obtaining improvements for the portals [36].

The coproduction component creates a more directed relationship citizen-government to produce, to share and to create data for the public decision-making. The idea to link two previous components: information value and accountability into this component is to promote citizen participation in the task of generating more value to public data and at the same time to improve tools and sections for the accountability area [50].

Finally the main objective of the institutional arrangements component is to measure the different organizational outcomes, agency changes and transformations as a result of open government tasks. This component is directly linked to the legal obligations, because both share law as a common basis to make changes in the public administration [57].

\subsection{Sample and Instrument}

This research is based on a content analysis of 59 state government transparency websites in Brazil and Mexico, what includes one website for each federal state in both countries (27 cases in Brazil, and 32 in Mexico). Our assessment is based on a presence/absence analysis of 50 variables referring to open government and transparency activities, selected out of ten key issues referring to five dimensions each of open government assessment: 1) legal arrangements, 2) open data environment, 3) verti- cal collaboration activities, 4) horizontal collaboration activities and 5) interface.

Our instrument of analysis was previously applied to
Mexican websites e-government transparency portal evaluations [14] and it was adapted for our comparative study after two pilot waves of survey using three randomly-selected websites in each country. Data in both countries were collected in February of 2013, and variables were coded, as present when within a maximum of two clicks away from the home page the observed activity could be located.

\section{Findings \& Discussion}

This section presents the main findings of the research, firstly presented the overall findings of the comparison between the two countries, the next section analyses each case separately.

\subsection{Overall Scores}

Mexico and Brazil present similar overall scores (see Table 1). Out of the 50 variables observed, the compliance percentage is of $46 \%$ in Brazil and $48 \%$ in Mexico. Brazilians compliance percentage is better than Mexico in terms of Open data framework (58\% vs. $45 \%)$ and Interface (70\% vs. $60 \%$ ). Mexican websites perform better than Brazil in terms of Legal arrangements framework (74\% vs. $57 \%)$, Vertical collaboration (48\% vs. $41 \%$ ) and Horizontal collaboration (14\% vs. $7 \%$ ).

It is significant the variability of compliance percentage within the same country. In Mexico in Brazil for example we find websites with very different maximum and minimum compliance scores in the framework of legal arrangements (100\% vs. $0 \%$, in both countries). Two frameworks appear with maximum scores at least once in both countries (legal arrangements and the interface frameworks) what is not true for Open data (maximum of $90 \%$ score in both countries), Vertical collaboration score (Maximum of $80 \%$ in both countries) and Horizontal collaboration (maximum of $50 \%$ score in Mexico and 30\% in Brazil).

The comparison of the overall score of one framework against the other, the highest score found in Brazil refers to the interface framework $(70 \%)$ followed by Open data and Legal arrangements (58\% and 57\%, respectively). In Mexico, the highest score refers to the Legal arrange- 
Table 1. Overall percentage scores, per country and framework $(\operatorname{Min}=0$, Max = 100).

\begin{tabular}{lcccccc}
\hline \multirow{2}{*}{ Framework } & \multicolumn{3}{c}{ BRA } & \multicolumn{3}{c}{ MEX } \\
\cline { 2 - 7 } & Mean & Max & Min & Mean & Max & Min \\
\hline A) Legal & 57 & 100 & 0 & 74 & 100 & 10 \\
arrangements & 58 & 90 & 30 & 45 & 90 & 10 \\
B) Open data & 51 & 80 & 0 & 48 & 80 & 20 \\
C) Vertical & 41 & & & & & \\
Collaboration & 7 & 30 & 0 & 14 & 50 & 0 \\
D) Horizontal & & & & & & \\
Collaboration & 70 & 100 & 30 & 60 & 100 & 10 \\
E) Interface & $\mathbf{4 6}$ & $\mathbf{7 6}$ & $\mathbf{1 6}$ & $\mathbf{4 8}$ & $\mathbf{7 6}$ & $\mathbf{1 4}$ \\
Overall score & $\mathbf{4 6}$
\end{tabular}

ments framework (74\%), followed by Interface $(60 \%)$ and Vertical collaboration (48\%). In both countries the lowest score falls into the Horizontal collaboration framework (14\% in Mexico and 7\% in Brazil).

Accordingly to this data we can hypothesize that in Mexico and Brazil the design of transparency websites is pushed forward by a concern with Legal arrangements and Interface criteria (the highest overall scores in both countries). This is related to the basic idea of open government into a one-way communication with citizens. On the other hand the inclusion of vertical and horizontal tools for collaboration is the lowest overall score in both countries. Taken together, we can suggest that transparency portals in both countries are better designed in terms of passive access to information (focusing on issues such as what information to display, and how to find it) rather than focusing on designing tools for citizens to interact with it (either vertically, such as performing tasks to share information in other social networks, or horizontally, such as commenting on information in the own transparency portal).

\subsection{Overall Scores by Framework of the Model}

We then analyze the overall performance of the Legal arrangement framework we observe that Mexican websites perform better than Brazilian websites. Not only the overall score of this framework is higher in Mexico than in Brazil ( $74 \%$ vs. $57 \%$ of compliance score), as much as Mexico performs better than Brazil in 6 out of 10 observed variables (A01 to A05, and A10). Mexican websites perform better than Brazilian websites particularly when presenting the transparency agency's program (A01, 91\% vs. 37\%), presenting the name of public servants working for the agency (A03, $88 \%$ vs. $33 \%$ ) and presenting information about private data access and use (A10, $69 \%$ vs. $15 \%$ ). Brazilian websites perform better (by a narrow margin) than Mexican websites when presenting auditory results of contracted goods and services (A08, $78 \%$ vs. $69 \%$ ), presenting applicable open gov- ernment and data transparency legislation (A09, 93\% vs. $84 \%$ ), and presenting information about programs' executive status (A07, $81 \%$ vs. $78 \%$ ). Brazilian websites however generally perform better than Mexican websites when presenting legal objectives of the agency (59\% vs. $41 \%)$.

Legal arrangements-When we compare both countries in terms of type of legal arrangements presented in the transparency portals, we notice that Brazilian websites perform better in regards of presenting government projects information than Mexico does (see variables A07, A08 and A09), while Mexico performs better when presenting information about the transparency agency itself (see variables A01 to A05).

Based on the findings of the legal arrangement framework we can hypothesize that Mexican websites were carefully designed to present information required by law in regards of agency information: agency's organogram and address, administrative objectives, and public servant's names and wages. The same cannot be said about Brazil: the average compliance score in the country is low in relation to presenting agency's organogram (37\%), agency's public servant names (33\%) and unit's objectives $(41 \%)$. However when it comes to presenting detailed information about government projects however the opposite happens and Brazilian websites perform better than Mexican websites do: they present slightly more detailed information about executive status of contracted goods and services and auditory results.

Open data framework-We observe that Brazilian websites perform better than Mexican websites. The overall compliance score of this framework is higher in Brazil than in Mexico (58\% vs. $45 \%$ of compliance score), but each country performs better in five of the 10 observed variables. Brazil performs better in presenting detailed information of contracted goods (B02, 100\% vs. $69 \%$ ), presenting information in a searchable format (B03, $100 \%$ vs. $63 \%$ ), offering downloadable information in an editable format (B04, $63 \%$ vs. $22 \%$ ), offerings specific tools to find information of open data documents (B05, 96\% vs. $22 \%$ ), offering a repository o readable files (B09, 96\% vs. 3\%); Mexico however performs better than Brazil in presenting procedures of decisionmaking (B01, 38\% vs. $34 \%$ ), presenting comparable information between different periods of time (B05, 66\% vs. $33 \%$ ), offering catalogues of open data information (B06, $47 \%$ vs. $30 \%$ ), statistical access information of the transparency website (B08, 66\% vs. $22 \%$ ), and using external indexes of open governance (B10, $53 \%$ vs. $4 \%$ ).

Two rarely found tasks in both countries refer to presenting procedures of decision-making (33\% BRA and $38 \%$ MEX) and presenting catalogues of open data information (30\% BRA and 47\% Brazil).

- A sharp difference between Brazil and Mexico in 
terms of open data can be found in offering tools to search, present and download information related to contracted goods and services. While in Brazil almost every website offers such tasks $(100 \%$ and $96 \%$, respectively) the same is not true in Mexico (69\%, 63\% and $22 \%$, respectively).

- Another sharp difference between countries can be found in regards of presenting information about statistical access of websites $(66 \%$ of the cases in Mexico offer this task, compared to $22 \%$ of the cases in Brazil) and offering tools to compare information across periods of time ( $66 \%$ of Mexican websites offer this tool, compared to $33 \%$ of the cases in Brazil).

Vertical collaboration-On this framework we observe that Mexican websites perform better than Brazilian websites by a narrow margin ( $48 \%$ vs. $41 \%$, respectively). It should be noted however that in general most variables in this framework score low for both countries. Two variables are frequently found in both countries ( $\mathrm{C} 02$, possibility to request information online, 74\% BRA and 94\% MEX; C10, directing citizens to other government institutions in case of need, 93\% BRA and $81 \% \mathrm{MEX}$ );

Also on this framework, three variables are frequently found in at least one of the countries ( $\mathrm{C} 03$, requesting private information online, 26\% BRA and 91\% MEC; $\mathrm{C} 05$, sending comments and requests about the website online, $70 \%$ BRA and 41\% MEX; and C07, hosting a specific form or email account to receive requests from citizens, 74\% BRA and 53\% MEX). And five variables are found in less than $1 / 3$ of the cases in both countries: C01, hosting online surveys, 11\% BRA and 31\% MEX; C04 offering online evaluation website surveys, $11 \%$ BRA and 28\% MEX; C06, filing a complain against a public servant, 19\% BRA and 31\% MEX; C08, finding information about public hearings, 33\% BRA and 13\% MEC; and C09, offering specific apps to use information in mobile and other hardware, 0\% BRA an 13\% MEX.

Summarizing, we can argue that vertical collaboration is implemented in a very basic level in both countries. Although it is possible for example to request information online in more than three out of four websites in both countries ( $74 \%$ BRA and 94\% MEX), the only other tasks found in similar frequency is directing citizens to other government institutions in case of need (93\% BRA and $81 \% \mathrm{MEX}$ ). Websites offer very infrequently tools to evaluate the transparency website (evaluation surveys appear only in $11 \%$ of Brazilian and $28 \%$ of Mexican websites), or to request specific information (such as filing a complain against a public servant, what is found in $19 \%$ of Brazilian and $31 \%$ of Mexican websites). Also, both countries websites rarely offer online surveys $(11 \%$ BRA and $31 \% \mathrm{MEX})$ or calls for public hearings $(33 \%$ BRA and $13 \%$ MEX).

Horizontal collaboration-The purpose of this frame- work was to observe that Mexican websites perform better than Brazilian websites by a narrow margin (14\% vs. $7 \%$, respectively). It should be noted however that in general most variables in this framework score low or are not found.

- In none of the observed websites information could be commented online (D01) or wiki pages editable by citizens were in use (D03);

- In very few of the observed websites there were online chat tools (D02) or forums for citizens to deliberate amongst themselves (D04).

- In Brazil, no website observed offered pages open for citizen's commentary, nor wikis, forums, online chat tools, public consultations hosted online or blogs. The most frequent tools of horizontal collaboration found (and even so, in less than one in five observed websites) are Facebook and Twitter accounts (D05 and D06) and sharing tools of online content (D10).

- In Mexico, no variables of horizontal collaboration were found in more than one third of the observed cases. The most frequent tools found refer to hosting public consultations online (28\%), having Twitter and Facebook accounts (31\% and $25 \%$, respectively) and hosting tools for sharing webpage information online $(19 \%)$.

- Interface-On this framework we observe that Brazilian websites perform better than Mexican websites by a narrow margin (70\% vs. $60 \%$, respectively). It should be noted that in general most variables in this framework score high in compliance scores.

- Four variables can be found in both countries in more than one third of the observed websites: the use of non-technical language (E01, 93\% BRA and 97\% MEX), homepage information organized by categories (E02, 100\% BRA and 84\% MEX) and updated up to 2013 (E04, 96\% BRA and 72\% MEX), and use of detailed information accessible with aid of external files or websites (E08, 96\% BRA and 94\% MEX);

- One variable is very infrequently found in both countries: accessibility standards or tools (E10, 33\% BRA and $22 \% \mathrm{MEX}$ );

- The use of website maps, glossary or FAQ section is common in Brazil, but not in Mexico ( $81 \%$ vs. $13 \%$ respectively). The opposite is true in relation to categorization of home page information by access number or release date (E07, 15\% BRA and 47\% MEX).

\subsection{Case Studies: Brazil}

The highest compliance score found in the Brazilian sample belongs to Pernambuco (BRA17), 76\%, followed by São Paulo (BRA25, 68\%), Ceará (BRA06, 66\%), Espírito Santo (BRA08, 64\%) and Paraná (BRA16, 64\%). The lowest scores in the country refers to the states of Mato Grosso do Sul (BRA12) and Acre (BRA01), with a 
score of $16 \%$, followed by the states of Mato Grosso (BRA11), 22\%, Piauí (BRA18) with 30\% and Amazonas (BRA04) with $32 \%$. Out of the 27 observed cases, 12 present compliance scores higher than 50\% (See Table 2).

When we observe the top three and bottom three websites in Brazil, we notice that by far the Horizontal Collaboration framework is the only largely missing feature in the top three websites (PE 10\%, SP 0\%, CE 10\%), what is true for the bottom websites of AC and MT $(0 \%$ each) but not applicable to the MS website (four out of ten variables of horizontal collaboration observed were found in this website) (See Table 3). It should be noted that the top three websites commonly present higher scores in the reaming observed frameworks, what is certainly not true in the bottom three websites.

Table 2. Individual compliance scores, Brazil only $(\mathrm{Min}=\mathbf{0}$, Max = 100).

\begin{tabular}{|c|c|}
\hline Website (BRA) & Score \\
\hline BRA-17.PE & 76 \\
\hline BRA-25.SP & 68 \\
\hline BRA-06.CE & 66 \\
\hline BRA-08.ES & 64 \\
\hline BRA-16.PR & 64 \\
\hline BRA-21.RS & 62 \\
\hline BRA-24.SC & 60 \\
\hline BRA-07.DF & 58 \\
\hline BRA-13.MG & 58 \\
\hline BRA-22.RO & 58 \\
\hline BRA-19.RJ & 54 \\
\hline BRA-10.MA & 50 \\
\hline BRA-03.AP & 48 \\
\hline BRA-23.RR & 46 \\
\hline BRA-15.PB & 44 \\
\hline BRA-27.TO & 44 \\
\hline BRA-09.GO & 40 \\
\hline BRA-02.AL & 38 \\
\hline BRA-05.BA & 38 \\
\hline BRA-14.PA & 38 \\
\hline BRA-26.SE & 38 \\
\hline BRA-20.RN & 32 \\
\hline BRA-04.AM & 30 \\
\hline BRA-18.PI & 26 \\
\hline BRA-11.MT & 22 \\
\hline BRA-01.AC & 16 \\
\hline BRA-12.MS & 16 \\
\hline
\end{tabular}

Table 3. Top three and bottom three websites per framework, Brazil only $(\operatorname{Min}=0, \operatorname{Max}=100)$.

\begin{tabular}{lccccccc}
\hline Framework & PE & SP & CE & MT & AC & MS & BRA \\
\hline $\begin{array}{l}\text { A) Legal } \\
\text { arrangements }\end{array}$ & 100 & 100 & 70 & 30 & 10 & 30 & 57 \\
$\begin{array}{l}\text { B) Open data } \\
\text { C) Vertical }\end{array}$ & 90 & 80 & 90 & 40 & 40 & 10 & 58 \\
$\begin{array}{l}\text { Collaboration } \\
\text { D) Horizontal }\end{array}$ & 10 & 60 & 70 & 10 & 0 & 0 & 41 \\
$\begin{array}{l}\text { Collaboration } \\
\text { E) Interface }\end{array}$ & 100 & 100 & 90 & 30 & 30 & 30 & 70 \\
Overall & $\mathbf{7 6}$ & $\mathbf{6 8}$ & $\mathbf{6 6}$ & $\mathbf{2 2}$ & $\mathbf{1 6}$ & $\mathbf{1 6}$ & $\mathbf{4 6}$ \\
\hline
\end{tabular}

\subsection{Case Studies: Mexico}

The highest compliance score found in the Mexican sample belongs to Nuevo León (MEX19), 76\%, followed by Queretaro (MEX22, 74\%), Distrito Federal (MEX09, $66 \%$ ), Guanajuato (MEX12, 64\%) and Durango (MEX10, $64 \%$ ). The lowest scores in the country refers to the states of Tlaxcala (MEX29, 14\%), Coahuila (MEX07, 26\%), Chiapas (MEX05, 28\%), Morelos (MEX17, 32\%) and Baja California Sur (MEX03, 34\%). Out of the 32 observed cases, 15 present compliance scores higher than 50\% (See Table 4).

When we observe the top three and bottom three websites in Mexico, we notice that the three top websites score maximum in the legal arrangements framework, and score high in the Interface framework, while the lowest scores are found in the horizontal collaboration framework. The three bottom websites have no pattern when compared cross-framework scores: Tlaxcala scores low in all frameworks, except Vertical collaboration; Coahuila scores high in Legal arrangements, but low in the remaining frameworks; Chihuahua scores mid-low scores in all frameworks (See Table 5).

\section{Conclusions \& Future Research}

The purpose of this paper is to implement an assessment model for open government portals. The comparison between two countries provides good evidence to prove the usefulness of the model. One of the main advantages is to identify strengths and weaknesses of each framework for the countries. One of the main findings of the model is the purpose of the open government portal, data present that Brazilian and Mexican Governments are focused on present information neither to provide interactive tools for citizens and the information.

Also the very low levels of use between horizontal and vertical collaboration support this argument and provide some practical suggestions for governments to implement more interaction in the open government portals.

Future research paths are as follows: open government 
Table 4. Individual compliance scores, Mexico only (Min = 0, $\operatorname{Max}=100$ ).

\begin{tabular}{|c|c|}
\hline Website (MEX) & Score \\
\hline MEX-19.Nue & 76 \\
\hline MEX-22.Que & 74 \\
\hline MEX-09.Dis & 66 \\
\hline MEX-12.Gua & 64 \\
\hline MEX-10.Dur & 60 \\
\hline MEX-21.Pue & 60 \\
\hline MEX-02.Baj & 58 \\
\hline MEX-08.Col & 58 \\
\hline MEX-24.San & 58 \\
\hline MEX-26.Son & 58 \\
\hline MEX-01.Agu & 54 \\
\hline MEX-15.Jal & 54 \\
\hline MEX-18.Nay & 54 \\
\hline MEX-23.Qui & 52 \\
\hline MEX-28.Tam & 50 \\
\hline MEX-04.Cam & 48 \\
\hline MEX-11.Est & 46 \\
\hline MEX-25.Sin & 46 \\
\hline MEX-31.Yuc & 46 \\
\hline MEX-14.Hid & 44 \\
\hline MEX-20.Oax & 44 \\
\hline MEX-13.Gue & 42 \\
\hline MEX-32.Zac & 42 \\
\hline MEX-16.Mic & 40 \\
\hline MEX-30.Ver & 38 \\
\hline MEX-06.hi3 & 36 \\
\hline MEX-27.Tab & 36 \\
\hline MEX-03.Baj2 & 34 \\
\hline MEX-17.Mor & 32 \\
\hline MEX-05.Chi & 28 \\
\hline MEX-07.Coa & 26 \\
\hline MEX-29.Tla & 14 \\
\hline
\end{tabular}

Table 5. Top three and bottom three websites per framework, Mexico only $(\operatorname{Min}=0, \operatorname{Max}=100)$.

\begin{tabular}{lccccccc}
\hline \multicolumn{1}{c}{ Framework } & Nue & Que & Dis & Chi & Coa & Tla & MEX \\
\hline $\begin{array}{l}\text { A) Legal } \\
\text { arrangements }\end{array}$ & 100 & 100 & 100 & 40 & 70 & 10 & 74 \\
$\begin{array}{l}\text { B) Open data } \\
\text { C) Vertical }\end{array}$ & 70 & 50 & 80 & 40 & 20 & 0 & 45 \\
$\begin{array}{l}\text { Collaboration } \\
\text { D) Horizontal }\end{array}$ & 80 & 70 & 60 & 30 & 20 & 40 & 48 \\
Collaboration & 40 & 50 & 20 & 10 & 0 & 10 & 14 \\
E) Interface & 90 & 100 & 70 & 20 & 20 & 10 & 60 \\
Overall & $\mathbf{7 6}$ & $\mathbf{7 4}$ & $\mathbf{6 6}$ & $\mathbf{2 8}$ & $\mathbf{2 6}$ & $\mathbf{1 4}$ & $\mathbf{4 8}$ \\
\hline
\end{tabular}

portals standards to present information; develop a single platform to share data and process with citizens and provide interaction. Another important path is to test the assessment model with other countries or within government agencies to provide feedback and identify problems or lacks for the portal.

Finally this assessment model in the case of Brazil and Mexico is the first step into a new way to understand the open government idea more focused on citizen-oriented and less on accomplishing legal requirements.

\section{REFERENCES}

[1] R. A. Chapman and M. Hunt, "Open Government in a Theoretical and Practical Context," Ashgate, Aldershot, Hants, England, Burlington, 2006.

[2] J. C. Bertot, P. T. Jaeger and J. M. Grimes, "CrowdSourcing Transparency: ICTs, Social Media, and Government Transparency Initiatives," Digital Government Society of North America, 2010.

[3] J. C. Bertot, P. T. Jaeger and J. M. Grimes, "Promoting Transparency and Accountably through ICTs, Social Media, and Collaborative E-Government," Transforming Government: People, Process and Policy, 2011.

[4] T. Nam, "New Ends, New Means, but Old Attitudes: Citizens' Views on Open Government and Government 2.0," 44th Hawaii International Conference on System Sciences (HICSS-44), Hawaii Manoa, 2011, pp. 1-10.

[5] J. C. Bertot, P. McDermott and T. Smith, "Measurement of Open Government: Metrics and Process," 45th Hawaii International Conference on System Science (HICSS), 2012, pp. 2491-2499.

[6] F. Steibel and F. Betramelli, "Policy, Research and Online Public Consultations in Brazil and Uruguay," In: B. Girard and A. Lara, Eds., Impact 2.0: New Mechanism for Linking Research and Policy, Fundación Comunica, Montevideo, 2012, pp. 87-126.

[7] I. A. Elbadawi, "The State of Open Government Data in GCC Countries," 12th European Conference on eGovernment (ECEG 2012), Barcelona, 2012, pp. 193-200.

[8] B. Ngwenya, S. Lubbe and R. Klopper, "Institutionalisation, Framing, and Diffusion: The Logic of Openness in eGovernment and Implementation Decisions (a Lesson for Developing Countries)," Proceedings of ICEG 2010: The 6th International Conference on e-Government, Cape Town, 2010, pp. 74-81.

[9] J. C. Bertot, P. T. Jaeger and D. Hansen, "The Impact of Polices on Government Social Media Usage: Issues, Challenges, and Recommendations," Government Information Quarterly, Vol. 29, No. 1, 2012, pp. 30-40.

[10] A. Hoffman, "La Transparencia y la Opacidad de los Gobiernos en México: Un Corte de Caja," Politica Digital, 2010.

[11] S. Lopez Ayllon, "Medir la Transparencia: Un Imperativo," Politica Digital, Vol. 26, 2005, pp. 24-30.

[12] S. Lopez Ayllon, "La Opacidad de la Transparencia," Politica Digital, No. 65, 2011, pp. 24-27. 
[13] R. Sandoval-Almazan, "Midiendo la Transparencia en Internet: Ranking de las Páginas Web de los Institutos de Transparencia en Mexico," In: C. Herrera, G. Lizama and L. Morales, Eds., Federalismo Y transparencia en Mexico: Seis Estudios de Caso, 1st Edition, Vol. 1, Alianza Civica-COmunidad Europea, Ciudad de Mexico, 2009, pp. 219-247.

[14] R. Sandoval-Almazan, "Open Government in Mexico. An Assessment Preview 2007-2010," Conference for E-Democracy and Open Government, Vol. 1, Danube University, Krems, 2012, pp. 255-266.

[15] G. Cejudo, S. Lopez Ayllon and A. Cazarez, "Diganóstico de la Transparencia en México: lecciones de la Metrica de Transparencia 2010," Revista Mexicana de Acceso a la Información y Protección de Datos Personales, 2011, pp. 58-81.

[16] R. Sandoval-Almazan, "Ranking de Portales de Transparencia: La medición 2010,” Política Digital, 2010, pp. 30-37.

[17] C. Ali, "e-gov.br: A Próxima Revolução Brasileira : Eficiência, Qualidade e Democracia: O Governo Eletrônico no Brasil e no Mundo," 1st Edition, Vol. 1, Pearson Prentice Hall, São Paulo, 2004.

[18] J. A. G. de Pinho, "Investigando Portais de Governo Eletrônico de Estados no Brasil: Muita Tecnologia, Pouca Democracia," Revista de Administração Pública, Vol. 42, No. 3, 2008, pp. 471-493.

[19] R. Sampaio, "Governança Eletrônica no Brasil: Limites e Possibilidades Introduzidos pelo Orçamento Participativo na Internet," Planejamento e Políticas Públicas, Vol. 33, 2009, pp. 124-143.

[20] C. Guilherme and N. Solano, "Acesso à Informação e Controle Social das Políticas Públicas," Agência de Notícias dos Direitos da Infância, Vol. 1, 2009, p. 127.

[21] C. V. José, M. R. Manuella and M. Ricardo, "Dados Governamentais Abertos e seus Impactos Sobre os Conceitos e Práticas de Transparência no Brasil," Democracia e Interfaces Digitais para a Participação Pública, Vol. 9, 2010.

[22] D. Silva, "Transparência na Esfera Pública Interconectada e Dados Governamentais Abertos," In: S. Silveira, Ed., Cidadania e Redes Digitais, Comite Gestor Da internet no Brasil, Sao Paolo, 2010, pp. 11-135.

[23] D. Rothberg and L. Maine, "Avaliação de Informações Sobre Políticas de Saúde em Portais," Revista Brasileira de Ciência, Tecnologia e Sociedade, Vol. 2, No. 1, 2011, pp. 226-238.

[24] W. Parks, "The Open Government Principle: Applying the Right to Know under the Constitution," The George Washington Law Review, Vol. 26, No. 1, 1957, pp. 1-22.

[25] L. W. Beer, "Freedom of Information and the Evidentiary Use of Film in Japan: Law and Sociopolitics in an East Asian Democracy," The American Political Science Review, Vol. 65, No. 4, 1971, p. 1119.

[26] H. C. Relyea, "The Provision of Government Information: the Federal Freedom of Information Act Experience," Canadian Public Administration, Vol. 20, No. 2, 1977, pp. 317-341.
[27] D. A. Drachsler, "Freedom of Information Act and the Right of Non-Disclosure," The Administrative Law Review, Vol. 28, 1976, p. 1.

[28] R. A. Morris, B. D. Sales and J. J. Berman, "Research and the Freedom of Information Act," American Psychologist, Vol. 36, No. 8, 1981, pp. 819-826.

[29] H. Bertil Wennergren, "Freedom of Information in Nordic Countries: Recent Developments," Government Publications Review, Vol. 10, No. 1, 1983, pp. 11-17.

[30] Y. Okudaira, "Toward Freedom of Information: The Japanese Case," Government Publications Review, Vol. 10, No. 1, 1983, pp. 71-79.

[31] C. Bennett, "From the Dark to the Light: The Open Government Debate in Britain," Journal of Public Policy, Vol. 5, No. 2, 1985, pp. 187-213.

[32] A. Hubbertz, "Freedom of information and Canadian Crown Corporation," Government Information Quarterly, Vol. 3, No. 1, 1986, pp. 63-71.

[33] A. Hubbertz, "Crown Copyright and Privatization of Government Information in Canada, with Comparisons to the United States Experience," Government Publications Review, Vol. 17, No. 2, 1990, pp. 159-165.

[34] H. C. Relyea, "Access to Government Information in the Information Age," Public Administration Review, Vol. 46, No. 6, 1986, p. 635.

[35] P. Birkinshaw, "Freedom of Information," Parliamentary Affairs, Vol. 50, No. 1, 1997, pp. 166-181.

[36] A. S. Roberts, "Less Government, More Secrecy: Reinvention and the Weakening of Freedom of Information Law," Public Administration Review, Vol. 60, No. 4, 2000, pp. 308-320. http://dx.doi.org/10.1111/0033-3352.00093

[37] A. S. Roberts, "Spin Control and Freedom of Information: Lessons for the United Kingdom from Canada," Public Administration, Vol. 83, No. 1, 2005, pp. 1-23. http://dx.doi.org/10.1111/j.0033-3298.2005.00435.x

[38] J. A. Shuler, "Citizen-Centered Government: Information Policy Possibilities for the 108th Congress," Journal of Academic Librarianship, Vol. 29, No. 2, 2003, pp. 107110. http://dx.doi.org/10.1016/S0099-1333(02)00426-3

[39] J. A. Taylor, A. M. B. Lips and J. Organ, "Freedom with Information: Electronic Government, Information Intensity and Challenges to Citizenship," In: R. Chapman and M. Hun, Eds., Freedom of Information: Perspectives on Open Government in a Theoretical and Practical Context, Ashgate, Aldershot, 2006, pp. 125-138.

[40] K. E. Uhl, "The Freedom of Information Act Post-9/11: Balancing the Public's Right to Know, Critical Infrastructure Protection, and Homeland Security," American University Law Review, Vol. 53, No. 1, 2003, pp. 261-311.

[41] Obama, "Transparency and Open Governmen | The White House," 21-ene-2009.

[42] V. Gordon, "National Security Directive Declassification," Government Information Quarterly, Vol. 27, No. 4, 2010, pp. 322-328. http://dx.doi.org/10.1016/j.giq.2010.02.007

[43] P. McDermott, "Building Open Government," Govern- 
ment Information Quarterly, Vol. 27, No. 4, 2010, pp. 401-413. http://dx.doi.org/10.1016/j.giq.2010.07.002

[44] J. C. Bertot, P. T. Jaeger and J. M. Grimes, "Using ICTs to Create a Culture of Transparency: E-Government and Social Media as Openness and Anti-Corruption Tools for Societies," Government Information Quarterly, Vol. 27, No. 3, 2010, pp. 264-271. http://dx.doi.org/10.1016/j.giq.2010.03.001

[45] S. S. Dawes, "Stewardship and Usefulness: Policy Principles for Information-Based Transparency," Government Information Quarterly, Vol. 27, No. 4, 2010, pp. 377-383. http://dx.doi.org/10.1016/j.giq.2010.07.001

[46] B. S. Noveck, "Wiki Government: How Technology Can Make Government Better, Democracy Stronger, and Citizens More Powerful," Brookings Institution Press, Washington DC, 2009.

[47] S. Picazo-Vela, I. Gutierrez-Martinez and L. F. LunaReyes, "Understanding Risks, Benefits, and Strategic Alternatives of Social Media Applications in the Public Sector," Government Information Quarterly, Vol. 29, No. 4, 2012, pp. 504-511. http://dx.doi.org/10.1016/j.giq.2012.07.002

[48] M. McLuhan and E. McLuhan, "Laws of Media: The New Science," University of Toronto Press, Scholarly Publishing Division, Toronto, 1992.

[49] T. L. Friedman, "The World Is Flat: A Brief History of the Twenty-First Century," 1st Edition, Farrar, Straus and Giroux, New York, 2005.

[50] D. Tapscott and A. D. Williams, "Wikinomics: How Mass Collaboration Changes Everything," Portfolio, New York, 2006.

[51] D. West, B. S. Noveck and C. Sirianni, "Innovation in Government: How to Make the Public Sector Faster,
Smarter and More Connected," Brookings Institution, Washington D.C., 2009.

[52] C. Geiger and J. von Lucke, "Open Government Data: Free Accessible Data of the Public Sector," Proceedings of the International Conference for E-Democracy and Open Government, Danube University, Krems, 2011, pp. 265-278.

[53] Open Government Working Group, " 8 Principles of Open Government Data-OpenGovData.org," 8 Principles of Open Government Data, 2007.

[54] W. Dutton, G. A. Guerra, D. J. Zizzo and M. Peltu, "The Cyber Trust Tension in E-Government: Balancing Identity, Privacy, Security," Information Polity: The International Journal of Government \& Democracy in the Information Age, Vol. 10, No. 1-2, 2005, pp. 13-24.

[55] W. H. Dutton, "The Fifth Estate Emerging through the Network of Networks," Prometheus, Vol. 27, No. 1, 2009, pp. 1-15. http://dx.doi.org/10.1080/08109020802657453

[56] M. Castells, "Comunicación y Poder," Alianza Editorial, Madrid, 2009.

[57] W. W. Powell and P. J. DiMaggio, "The New Institutionalism in Organizational Analysis," 1st Edition, University of Chicago Press, Chicago, 1991.

[58] K. Senge, "The 'New Institutionalism' in Organization Theory: Bringing Society and Culture Back In," The American Sociologist, Vol. 44, No. 1, 2013, pp. 76-95. http://dx.doi.org/10.1007/s12108-012-9170-5

[59] W. Orlikowski, "Using Technology and Constituting Structures: A Practice Lens for Studying Technology in Organizations," Organization Science, Vol. 11, No. 4, 2000, pp. 404-428.

http://dx.doi.org/10.1287/orsc.11.4.404.14600 